\title{
Environmental mining limits in the North Bohemian Lignite
}

\section{Region}

Book review: Ríha, M., Stoklasa, J., Lafarová, M., Dejmal, I., Marek, J., Pakosta, P., Beránek, K. Environmental mining limits in the North Bohemian Lignite

Region. Společnost pro krajinu, Praha 2005. Translation: Petr Kurfürst.

\section{Andrew Barton}

Envigogika 8 (4) - Reviews

Published 31. 12. 2013

DOI: http://dx.doi.org/10.14712/18023061.418

\section{Abstract:}

This book review looks at the issue of mining limits in the region of North-West Bohemia in the Czech Republic and briefly summarises from the content of the book originally published in 2005 (in Czech, but later translated into English) supplemented with the most up-to-date information on the current situation..

\section{Keywords:}

book review, mining limits, North-West Bohemia 
The region of North-West Bohemia (Czech Republic) has always attracted the attention of the extractive industries in all their various guises over the centuries as a result of the rich mineral deposits to be found there. It is no coincidence that the hills bordering the region are known collectively as the Ore Mountains. The discovery of silver and tin in these mountains in the 12th century triggered the slow but steady settlement of the area.

But it was the discovery of coal lying alluringly close to the land surface that finally unleashed the full panoply of extractive technology on the region. And in the century and a half since the Industrial Revolution, the physical, cultural and social landscape of the Mostecko region in particular has been irreparably altered in the scramble to uncover the vast deposits of lignite located in the North Bohemian coal basin stretching roughly from Kadaň to Ústí nad Labem. In their eagerness to extract this fossilised bounty to fuel the burgeoning imperial and then national economy, successive regimes have contributed to the transformation of the region from what was once the protective gateway from Saxony into the Bohemian kingdom via the old royal city of Brüx (Most) with its surrounding expanse of rich and fertile fruit orchards, to today's panorama that is one part opencast lunarscape, one part recultivated slag heap, and one part uniform socialist-realist cityscape. A superficial extraction process began under the Austro-Hungarians and was gradually expanded during the First Republic as the first coal-fired power plants came online. Mining was massively expanded during the war years when Czech coal deposits were exploited with no regard to the environment to manufacture synthetic fuel at the giant chemical works in Záluží to drive the Nazi war machine. The practice of opencast extraction methods was continued and further expanded by the Czech authorities after the war, and the Záluží plant rebuilt. The apotheosis of coal was achieved under the communist regime following the takeover in 1948 when coal mining was ratcheted up even further to fuel a new rush for economic growth focused on heavy industry. At the same time, the nadir of environmental damage occurred from the late 1960s to the early $1980 \mathrm{~s}$ when in its desperation to scratch as much coal from the earth as possible, the communist regime sanctified the razing of over 100 villages and towns, including almost the entire city of Most that was depicted as a "decaying capitalist relic" (Glassheim, 2007, p.447). The combination of a regime hell-bent on mining brown coal by whatever means possible and at any cost and a militantly atheistic philosophy proved to be an especially poisonous cocktail for the region's religious structures: between 1945 and 1989, a total of 536 churches, chapels, monasteries, synagogues and Jewish cemeteries were destroyed in the Ústí region. The 104 churches alone that were razed over that time represent nearly half of all the churches that disappeared throughout the entire state of Czechoslovakia (Stehlík et al., n.d.). 


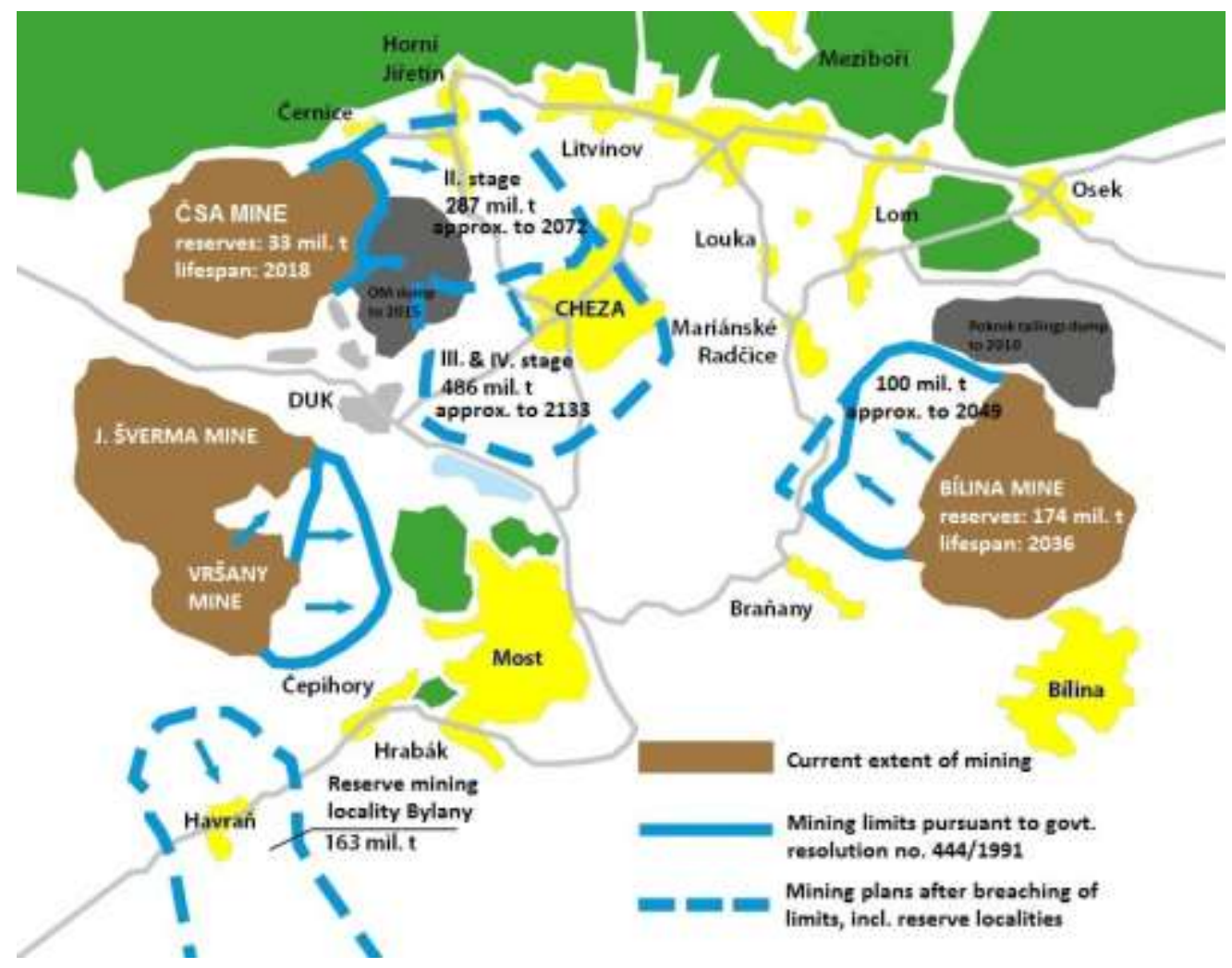

Figure 1. The North Bohemian brown coal mining limits as they apply to the Most region and plans for continued mining should the limits be repealed; yellow = built-up areas, green $=$ forested areas. Source: Kořeny o.s. (translated into English).

How could this possibly have happened? Surely there must have been some popular resistance under the liberalising regime in the run up to the Prague Spring and even during Husák's 'normalisation' years. One has to go back to the immediate post-war years to find the answer. In the immediate aftermath of the Nazi defeat, President Beneš issued the decrees that effectively ethnically cleansed the former Sudeten German population from Czechoslovakia, resulting in the sudden depopulation of the Ore Mountain and Mostecko regions. To fill the vacuum and re-establish the labour force necessary to work the mines, a completely new population was imported from other parts of Czechoslovakia on the promise of work opportunities and the assignment of property abandoned by the former inhabitants. These new settlers were therefore wholly lacking any connection to their natural, cultural and built environment. Moreover, many of them arrived out of socialist conviction and were therefore more than likely to be sympathetic to the goals of the regime to construct a new regional identity based on the productivist ideal of a society built on industrial modernity rather than the bucolic and romantic notions of the Sudeten German Heimat (Glassheim, 2006, p.91). No wonder then that the new settlers remained passive in the face of the wholesale demolition of the region, preferring to prioritise jobs and apartments in standardised prefabricated tenements over a healthy physical environment.

The pendulum finally swung back in favour of sensible regional management after the fall of the communist regime with the adoption of environmental mining restrictions by the newly democratic Czechoslovak parliament in 1991. This is the theme of Environmental mining limits in the North Bohemian Lignite Region, originally published in 2005 but only now available in English translation thanks to the Charles University 
Environment Center as part of the material it has collated for use by summer school students examining regional sustainability issues in the Ústí region (of which Mostecko and the Ore Mountains are a part). Its authors were all closely involved in the David versus Goliath battle to protect the remaining communities that lay directly in the path of the Brobdingnagian excavators. The fact that the mining operations were eventually ringfenced and strict no-go areas established is in large part down to the efforts of the authors of this book, both during the communist regime when it could be literally life-threatening to oppose state energy plans, and in the years after the re-establishment of democratic politics. The book documents in great detail the havoc wrought on the natural ecosystems and human landscape from an industry presented to the nation as providing the very lifeblood of the state economy (Glassheim, 2007, p.455), and in particular the struggle to convince the government of the potentially catastrophic folly of undermining the geological structures propping up the foothills of the Ore Mountains. Jan Marek, who worked as a geologist on the mining operations, details the efforts to save the heritage site at Jezeři Chateau that occupies a prominent position on the slopes on the Ore Mountains directly above the Czechoslovak Army Mine after his own geological survey convinced him that the encroaching mining operations would inevitably lead to a calamitous collapse of the chateau's geological foundations. At times the story can read like a thriller; indeed, the whole story of the mining of the North Bohemian coal basin and the various rapacious attitudes to the region adopted by successive regimes is worthy of a Tolstoyan novel 1 .

But, of course, the story doesn't end with the preservation of the chateau and the adoption of the mining limits. As Martin Říha and Petr Pakosta observe: "That was the turning point, and we as its orchestrators in the post-Velvet Revolution public administration believed that it would be permanent. It was not to be. The struggle continues 15 years later". That was written nearly 10 years ago, and indeed the struggle does continue to this very day. The limits began to be questioned almost as soon as they were enshrined in law. Leading politicians, especially since 2005 when the original 1991 resolution was due for review, have felt emboldened to publicly query their efficacy. State energy plans, while not openly advocating their repeal, have nevertheless planted the seeds of doubt in the public mind by emphasising the need for energy self-sufficiency without committing to a comprehensive plan to support a renewable energy industry. A classic example of this ambivalence, at least according to Greenpeace (Greenpeace, 2012), is to be found in two strategic energy plans promoted in 2012 by former Trade and Industry Minister Martin Kuba: while the draft State Energy Plan made no mention of breaching the mining limits, the Raw Materials Policy clearly counted on annulling the limits by the year 2018 to ensure there was enough domestic coal to supply the country's power and heating plants.

Moreover, the privatisation of the North Bohemian mining operations in the closing years of the last century introduced powerful new private interests into the plot. Leaving aside the massive fraud involved in the sale of the former Mostecká uhelná společnost (Most Mining Company) for which its former owners have recently been sentenced to prison terms and huge fines by a court in Switzerland, the current owner of the Czechoslovak Army Mine, Severní energetická, and its parent company, Czech Coal, have been accused by their detractors of engaging in underhand practices to build support for overturning the mining limits. Czech Coal would dearly love to get its hands on the profits that would ensue from extracting the hundreds of millions of tons of coal that lie beyond

\footnotetext{
${ }^{1}$ The battle to save Jezeři Chateau is also recorded in much detail from the perspective of the
} accompanying newspaper campaign by Pavel Koukal (2010). 
the limits, including under the townships of Horní Jiřetín and Černice, and beneath the gargantuan chemical plant in Záluží (shown in Figure 1 as CHEZA - CHEmický závod $v$ ZÁluží). Given that Horní Jiřetín is the key battleground in the fight to either retain or dismantle the limits, there is little love lost between the majority of the town's residents and the mining lobby. During the 2010 municipal elections, for example, there were allegations made that the mining company had used a proxy to purchase buildings in the town and then immediately populate them with occupants registered as new permanent town residents in order to influence the election outcome (Černý \& Janoušek, 2010). The very latest accusations focus on the "business deal of the century" Czech Coal struck earlier this year with the half state-owned energy giant ČEZ to supply its power stations with coal for the next 50 years at a cost of CZK 200 billion (Mladá fronta E15, 2013). That deal included the sale of the Chvaletice power plant to Czech Coal, even though it was unclear where all the coal required to fuel the plant would come from. The Czech Heating Plant Association alleged that Czech Coal had intentionally underestimated its available coal reserves in order to influence the price of domestic coal (Mladá fronta E15, 2013). More pertinently in terms of the mining limits, Czech Coal then miraculously discovered additional reserves at the Czechoslovak Army Mine with which it could maintain its commitment to supply Chvaletice. These deposits, however, lie near or across the boundary limits and are to be extracted through deep mines via a method known as pillar mining. Severní energetická hence applied to the state mining authorities in March this year to lift a ban on deep mining in two of the protective pillars that support the adjacent slopes of the Ore Mountains. Greenpeace suspects this is part of the campaign to chip away at the legal edifice of the mining limits and breach the environmental restrictions by stealth. The Ministry of Environment has already indicated that deep mining poses no serious risk to the environment, in which case mining is likely to begin next year.

More visibly, the mining lobby maintains a very public marketing campaign that plays upon local fears of increased joblessness in a region that already ranks near the bottom of national unemployment statistics (e.g. billboards depicting local residents in a range of occupations with the caption "I also have a job thanks to coal"2). Some of this campaign even implies that it is the patriotic duty of Czechs to dig and burn coal, e.g. "Don't pay for wind/sun. Choose Czech energy."3 Politicians are certainly on tune with the joblessness message, including some very unlikely bedfellows with the "coal barons" - the local communist party, which occupies the post of regional hejtman (governor) (Honzejk \& Fischer, 2012). This is despite the fact that the mining community has had over 20 years to adapt and requalify its workforce, leaving the impression that it never took the mining limits seriously and always intended to have them repealed.

Even though opponents of the mining limits like to complain of the "omnipresence" of the environmental lobby, supporters of the limits face an almost Sisyphean task to hold back the movement to lift the restrictions that has support across nearly the entire political spectrum. After President Klaus's failed attempts in 2012 to veto an amendment to the Mining Act that removed the option of compulsory acquisition of private property for mining purposes, President Zeman has more recently not been shy in voicing his opinion in favour of dismantling the limits. This was taken to farcical proportions when his placeman in the caretaker government that assumed power after the collapse of Petr Nečas's centreright government amid a corruption scandal in mid-2013, Premier Jiři Rusnok, stated in

\footnotetext{
${ }^{2}$ An example of this type of billboard can be viewed at http://www.czechcoal.cz/cs/novinky/aktuality/2013/20130211.html

${ }^{3}$ See the Severní energetická website at http://www.sev-en.cz/cz/index.html
} 
November that he was considering repealing the limits, which he called "outmoded and obsolete". This is an astonishing statement to make for two reasons: firstly, just three months earlier Rusnok claimed he was against lifting the limits, and secondly, he and his government not only had no mandate, the party vehicle that President Zeman was using to strengthen his otherwise relatively weak presidential powers - The Party of Civic Rights (Zeman's People), which included a number of Rusnok's own ministers who stood as candidates at the elections - had very recently been resoundingly thrashed at the ballot box, having collected a paltry $1.5 \%$ of the vote. Premier-in-waiting Bohuslav Sobotka was quick to say that Rusnok should make no decisions about the strategic direction of the country, including the mining limits.

Last minute attempts were made as a new coalition government came closer to fruition to justify Rusnok's determination to comply with Zeman's and the coal lobby's wish to dismantle the limits without regard to due political process that reeked of desperation and a clear misreading of the public mood (Rusnok's Trade and Industry Minister, Jiři Cienciala, even preposterously suggested that his government was "non-political" and was therefore better placed to make objective decisions about the mining limits (Cienciala, 2013)). Just prior to publication of this article, the final scene of this latest act was played out in parliament when members from all parties voted overwhelmingly in favour of a motion calling upon Rusnok's caretaker government not to make any strategic decision in regard to the North Bohemian mining limits. Rusnok finally conceded that he had no authority to act and would therefore leave the issue of the limits to the next government.

Rusnok's climbdown, however, merely signals the end of another see-sawing skirmish in the ongoing war. The real and potentially final battle over making the limits permanent has merely been postponed. The publication of the English version of Environmental mining limits in the North Bohemian Lignite Region comes at a crucial time just as the opencast mining operations at the Czechoslovak Army Mine approach the current limits and are hence slowly beginning to wind down. The struggle will only intensify from now on. Readers of this book will find that the arguments used for establishing the mining limits in 1991 are just as relevant today, if not even more so.

Note: A detailed description of the more recent battles to preserve or dismantle the mining limits pertaining to the Czechoslovak Army Mine can be viewed on Wikipedia at https://en.wikipedia.org/wiki/Brown_coal_mining_limits_in_North_Bohemia.

\section{References:}

- Cienciala,J. (5 December 2013). "Návrh vystoupení pana ministra", Lidové noviny.

- Černý, O., \& Janoušek, A. (12 October 2010). "Odpůrci těžby uhlí se bojí, že lobbisté v Horním Jiřetíně zmanipulují volby", Mladá fronta dnes. Available at http://usti.idnes.cz/odpurci-tezby-uhli-se-boji-ze-lobbiste-v-hornim-jiretinezmanipuluji-volby-163-/usti-zpravy.aspx?c=A101012_1464750_usti-zpravy_alh [retrieved 17 December 2013].

- Glassheim, E. (2007). Most, the Town that Moved: Coal, Communists and the 'Gypsy Question' in Post-War Czechoslovakia. Environment and History, 447-476.

- Glassheim, E. (2006). Ethnic Cleansing, Communism, and Environmental Devastation in Czechoslovakia's Borderlands, 1945-1989*. The Journal of Modern History, 78(1), 65-92. 
- Greenpeace. (7 November 2012). "Kubův návrh energetické koncepce s těžbou za uhelnými limity nepočítá, jinak ale nestojí za nic". Available at http://www.greenpeace.org/czech/cz/press/sek limity sea/ [retrieved 17 December 2013].

- Honzejk, P., \& Fischer,P. (19 October 2012). "Budoucí hejtman Bubeníček (KSČM): Lenina jsem na zed' nepověsil! Ale nesundám ho", Hospodářské noviny,. Available at http://zpravy.ihned.cz/politika/c1-57998550-budouci-hejtman-bubenicek-kscmlenina-jsem-na-zed-nepovesil-ale-nesundam-ho [retrieved 17 December 2013].

- Koukal, P. (2010). Bitva o Jezeří: z pohledu novinářských kampaní. Kapucín, Duchcov

- Mladá fronta E15 (21 April 2013). "Teplárníci: Czech Coal vodil za nos teplárny i ministerstvo", Mladá fronta dnes E15. Available at http://zpravy.e15.cz/byznys/prumysl-a-energetika/teplarnici-czech-coal-vodil-zanos-teplarny-i-ministerstvo-968099 [retrieved 17 December 2013].

- Stehlík, M., Hlaváček, T., Plachý, J., Kuča, K., Macek, P. (n.d.). Zničené kostely Severních Čech 1945-1989. Společnost pro obnovu památek Ústecka, o.s.ne

\section{Andrew Barton}

Charles University Environment Center, Charles University in Prague 